\title{
INVESTIGATION OF METHYL TETRAHYDRO- FOLATE REDUCTASE C677T POLYMORPHISM IN A SAMPLE OF PATIENTS IN A HOSPITAL BASED DIAGNOSTIC SETTING IN SRI LANKA
}

\author{
Varnakulasingham, $\mathrm{H}^{1^{*}}$ and Manamperi, $\mathrm{A}^{2}$ \\ ${ }^{1}$ University of Wolverhampton \\ ${ }^{2}$ University of Kelaniya
}

\begin{abstract}
The present study was conducted to identify the prevalence of MTHFR gene mutation in a group of Sri Lankan patients seeking routine diagnostic testing for the C677T mutation through PCR followed by RFLP diagnostic methods. Human MTHFR gene codes for the production of MTHFR enzyme in humans which plays major role in homocysteine and folate metabolism in humans. The mutation in MTHFR gene at nucleotide position 677 has two possibilities: C (cytosine, which occurs in the wild type gene) or $\mathrm{T}$ (thymine, which occurs in the mutated gene).In C677T variant, modification from $\mathrm{C}$ to $\mathrm{T}$ gives rise to the replacement of alanine by valine residue in protein at 222 aa position. Eight serum samples were collected from the MTHFR mutation suspected patients. Genomic DNA extraction was done and extracted DNA was subjected to PCR amplification. PCR products were subjected to RFLP assay with overnight digestion. The substitution of "C" to "T" at 677 position of MTHFR gene creates a restriction site for the enzyme Hind111. RFLP products were subjected to gel electrophoresis and further analysis. The results obtained shows that, of the 8 samples tested, 2 had 677CT genotype, 1 had 677TT genotype whereas the remaining 5 had $677 \mathrm{CC}$ wild type. Homozygous 677TT genotype leads to lower MTHFR activity and hyperhomocysteinaemia, which can cause defects in DNA repair. However, as this is a small sample of the population, it is recommended to carry out studies with a large sample volume to ascertain the prevalence of this mutation in the community.
\end{abstract}

Keywords: Methylene tetrahydrofolate reductase (MTHFR) gene mutation (C677T variant), Genotype, Hyperhomocysteinaemia, DNA repair, Restriction fragment length polymorphisms (RFLP), Polymerase chain reaction (PCR), Hind111.

\section{INTRODUCTION}

Methylene tetrahydrofolate reductase (MTHFR) is one of the most important enzymes in human body. Human MTHFR gene codes for the production of methylene tetrahydrofolate reductase (MTHFR) enzyme in humans. The 5, 10-methylene tetrahydrofolate reductase (MTHFR) enzyme catalyzes the conversion of 5, 10methylenetetrahydrofolate to 5methyltetrahydrofolate, the primary circulatory form of folate and a co substrate for homocysteine remethylation to methionine (Curtin et al., 2004). Folate is known as Vitamin B9 and it is required for the, Synthesis of DNA, RNA and SAMe, Single carbon metabolism or methylation, Amino acid metabolism (for neurotransmitter, serotonin, dopamine and norepinephrine production and detoxification), Formation and maturation of RBC (red blood cells), WBC (white blood cells) and platelet production and Essential for detoxification of homocysteine. For all these functions to happen with in the body, it needs to convert folate to active 5MTHF (5-methyltetrahydrofolate) with the help of co-factors (Leclerc, Sibani and Rozen, 2000).

The MTHFR gene is located on chromosome 1 at $\mathrm{P}$ arm p36.3 in humans. There are several DNA sequence variants are associated with this gene. In 2012 a report state that over 40 point mutations of

Corresponding Author Email: hesika1993@gmail.com 
this gene have been identified (Crider et al., 2012).There are two commonly recognized polymorphic variants in the gene encoding for this enzyme: They are C677T, and A1286C variant. Both are missense changes which can cause decrease enzyme activity. Reduced enzyme activity of MTHFR is a genetic risk factor for hyperhomocysteinemia, especially in the presence of low serum folate levels. Elevated Homocysteine level in blood is associated with various diseases including cardiovascular diseases, stroke, neural tube defects,
Spina bifida, High blood pressure, Glaucoma, certain types of cancer. (Eg. colorectal cancer, breast cancer, lung cancer etc.) and type 2 diabetes mellitus. Mild to moderate hyperhomocysteinemia has been identified as a risk factor for several diseases like cancers and cardiovascular diseases (Curtin et al., 2004).

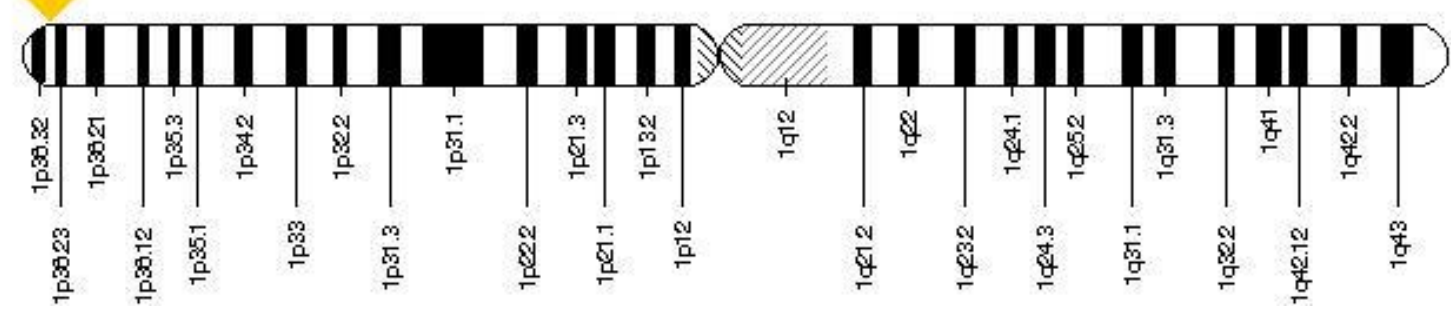

Figure 01 - The MTHFR gene is located on chromosome 1 (Albers et al., 2005).

According to this research mutation in the 677 base pair position of the MTHFR gene has been investigated. The mutation in MTHFR gene at nucleotide position 677 has two possibilities: C (cytosine, which occurs in the wild type gene) or $\mathrm{T}$ (thymine, which occurs in the mutated gene).In the C677T variant the nucleotide position at 677 is modified from $\mathrm{C}$ to $\mathrm{T}$ and this gives rise to the replacement of alanine by valine residue in the protein at 222 amino acid position (Kirke, 2004). Individuals with two copies of $677 \mathrm{CC}$ or $677 \mathrm{TT}$ have wild type or mutated genes respectively in both homologous chromosomes. Some individuals are heterozygous for this mutation where one homolog carries $\mathrm{C}$ residue and the other homolog carries $\mathrm{T}$ residue (Wang et al., 2012). Homozygous TT genotype is considered as harmful because it is associated with high concentration of total plasma Homocysteine level and lower MTHFR enzyme activity of $30 \%$, which can cause defects in DNA repair system in the enzyme. On the other hand, 677CT genotype has MTHFR enzyme activity of about $65 \%$ when compared to wild type (Curtin et al., 2004). 

Biochemical Mechanisms of Folate and Homocysteine Cycles

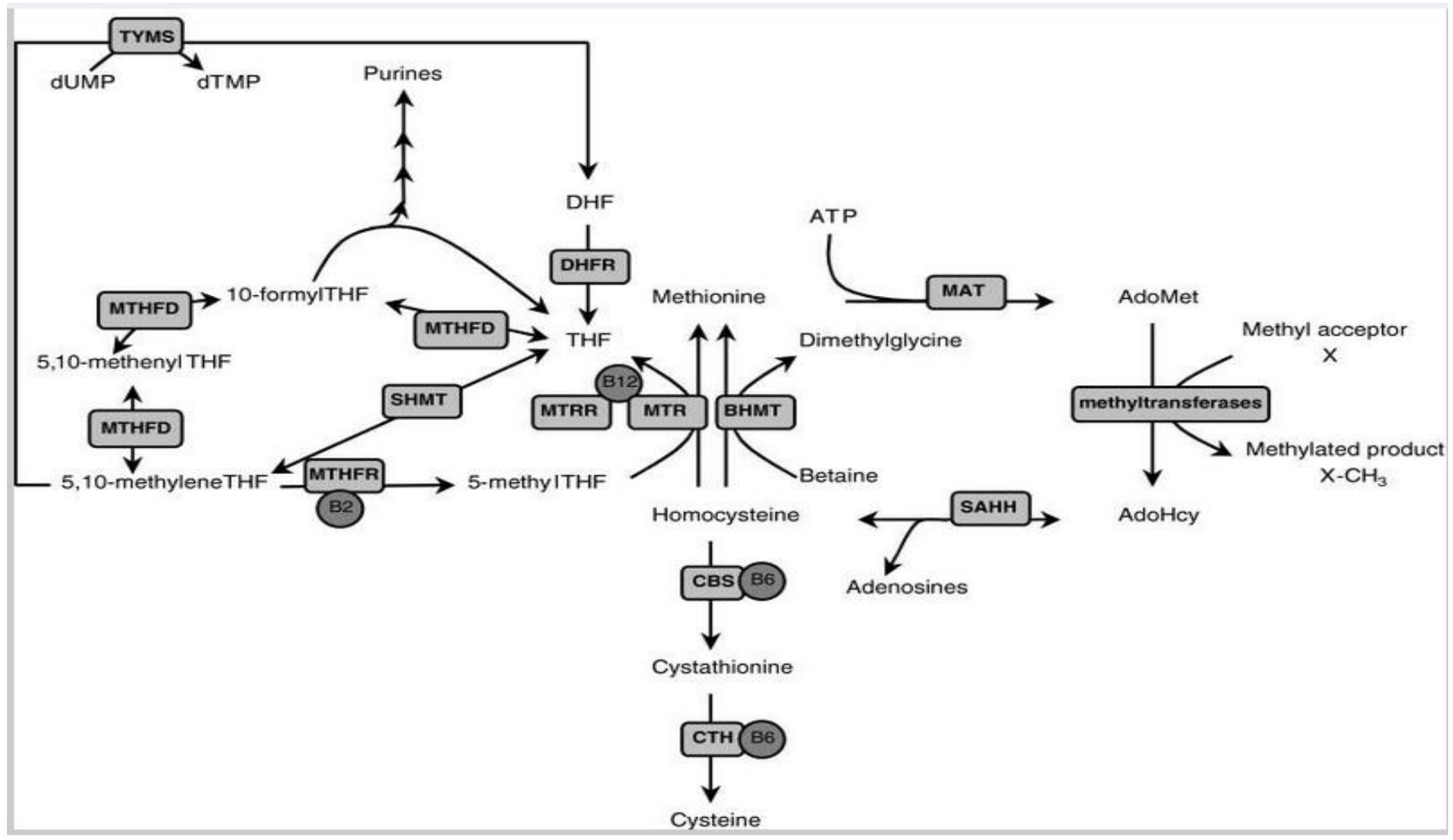

Figure - 02 Schematic representation of the folate cycles and homocysteine metabolism (Blom and Smulders, 2011). 


\section{Folate cycle}

5-methylTHF functions as a methyl donor for homocysteine remethylation. The resulting THF can directly be converted into 5, 10-methyleneTHF by the action of serine hydroxymethyltransferase (SHMT). SHMT is a vitamin B6-dependent enzyme that uses serine as a one-carbon donor. Conversion of THF into 5, 10-methyleneTHF, via 10-formylTHF and 5, 10methenylTHF, is catalyzed by the trifunctional enzyme methylenetetrahydrofolate dehydrogenase (MTHFD) that has formyltetrahydrofolate synthetase, methenyltetrahydrofolate cyclohydrolase and methylenetetrahydrofolate dehydrogenase activities (Blom et al., 2009). 5, 10-methylenetetrahydrofolate can be used as a cofactor for the conversion of deoxyuridine monophosphate (dUMP) into deoxythimidine monophosphate (dTMP). This reaction is catalyzed by the enzyme thymidylate synthase (TYMS) and produces dihydrofolate (DHF), which can induces reduction back to THF by the action of dihydrofolate reductase (DHFR). In addition to being a cosubstrate for dTMP synthesis, 5, 10methyleneTHF can also be reduced to 5-methylTHF by the riboflavin (vitamin B2)-dependent enzyme methylenetetrahydrofolate reductase (MTHFR). MTHFR enzyme has a great importance in the regulation of 5-methylTHF level for homocysteine remethylation (Forges et al., 2007).

\section{Homocysteine metabolism}

Homocysteine is a sulphur containg amino acid that is formed by the demethylation of the essential amino acid methionine through $\mathrm{S}$-adenosylmethionine (AdoMet) and S-adenosylhomocysteine (AdoHcy). Methionine adenosyltransferase (MAT) catalyse the formation of s-adenosylmethionine (AdoMet), which acts as the methyl donor in many methylation reactions such as methylation of DNA, RNA, hormones and lipids (Forges et al., 2007).The transmethylation of S-adenosylmethionine (AdoMet) by methyltransferase (MT) form Sadenosylhomocysteine (AdoHcy) which is an inhibitor of many methyltransferases. Hydrolysis of S-adenocsylhomocystein (SAH) by Sadenosylhomocystein hydrolase (SAHH) forms adenosine and homocysteine. The resulting homocysteine can be further metabolized in two pathways: transsulpuration pathway or remethilation pathway. In trassulpurination pathway, homocysteine is irreversibly degraded to cystathionine and cysteine. In remethilation pathway, it is remethylated to methionine (Blom et al., 2009).

\section{Remethylation}

Homocysteine can be re-methylated to methionine by two different pathways.

\section{Methionine synthase pathway}

Homocysteine (Hcy) is remethylated into methionine (Met) by MTR with 5-methylTHF as a methyl donor and cobalamin (B12) as a co-enzyme. 5-MethylTHF is produced by the FAD-dependent enzyme 5, 10Methylene tetrahydrofolate reductase (Leclerc, Sibani and Rozen, 2000). 5, 10-MethyleneTHF is also a onecarbon donor in the synthesis of thymidylate and after conversion into 5,10-methenyltetrahydrofolate (MethenylTHF) and further into 10formyltetrahydrofolate (FormylTHF), in the synthesis of purines. After the release of one-carbon all of these substituted folates are converted to THF which is finally recycled into MethyleneTHF during the conversion of serine to glycine by the enzyme serine hydroxymethyltransferase (SHMT). Met is further transformed into SAM. After release of the methyl group, SAM is converted into SAHH (Sadenosylhomocysteine hydrolase), which in turn hydrolyzed into Hcy (Crider et al., 2012).

\section{Betaine homocysteine methyltransferase (BHMT) pathway}

The alternative pathway by which Hcy is remethylated into Met takes place in the liver and uses betaine as a methyl donor; this reaction is catalyzed by the enzyme betaine homocysteine methyltransferase (BHMT) (Forges et al., 2007).

According to this mechanism 5, 10-methylene tetrahydrofolate reductase (MTHFR) enzyme catalyzes the conversion of 5, 10methylenetetrahydrofolate to 5methyltetrahydrofolate. During the absence of MTHFR due to C677T mutation 5-Methyl tetrahydro folate not produced. Along with that remethylation pathway also stopped because 5-Methyl tetrahydro folate acts as a factor in remethylation pathway. Therefore blood homocysteine level get elevated and cause hyperhomocysteneamia in the patients with this mutation. 


\section{Factots That Can Cause Hyperhomocystenaemia}

The cause of hyperhomocysteinaemia is multifactorial. In addition to genetic factors, a number of environmental factors also involve in elevated homocysteine concentrations. They are

\section{Age and sex}

Increasing age and male gender are strongly associated with increased homocysteine concentrations (Dedoussis et al., 2005). The gender difference of homocysteine concentration is attributed to many factors.

\section{Lifestyle factors}

Coffee consumption is independently associated with increased homocysteine concentration while association with smoking is dose dependent (Chrysohoou et al., 2004). The association between alcohol consumption and homocysteine concentration appears to be $\mathbf{J}$ shaped in both sexes. Therefore low intake of alcohol (1-2 units) is associated with lower homocysteine concentration resulting protective effect on cardiovascular mortality (Crider et al., 2012). High body mass index (BMI) too is associated with lower homocysteine levels (Blom and Smulders, 2011).

\section{Other factors}

Several drugs, such as antiepileptic drugs (Phenobarbitol, Valproate, Phenytoin etc), Methotrexate or lipid-lowering drugs (Cholestyramine, Fibric acid derivatives), Diuretics, Nitrous oxide, Estrogen-containing oral contraceptives, Metformin, Niacin, Theophylline and Sulfasalazine also can be increase plasma homocysteine level (Karabacak et al., 2014).

\section{Dietary factors}

Plasma homocysteine levels are regulated by several factors. Among the nutritional factors, deficiencies of vitamins B6, B12, and folate are associated with elevated plasma homocysteine concentrations. Supplementation with folic acid alone and in combination with vitamins B6 and B12 reduces the plasma homocysteine concentration (Yasui et al., 2000). The meta-analysis of the size of reduction of homocysteine concentration achieved by different doses of folic acid with or without vitamin B 12 and B6 in clinical trials. Both their first and second analyses concluded that addition of vitamin B12 to Folic acid reduced $25 \%$ of blood homocysteine level, while no significant effect was observed with the addition of vitamine B6 (Blom and Smulders, 2011).

Even though the relative importance of the environmental factors is not known, they exert their effects on homocysteine metabolism which is primarily determined by genetic composition of the individual. The genetic factors are more prominent in the young than in the old age group because cumulative effects of the environmental factors take time to modify the phenotype of the individual (Micheal et al., 2009).

\section{Genetics of Homocysteine}

A large number of studies had been conducted over the last several decades implicating genetic aetiology of homocysteine. One comprehensive analysis of studies conducted up to 2004 has identified 135 genes are related to homocysteine metabolism (Sharma et al., 2006). These genes are classified in to two groups; Genes that are involved in modulating homocysteine levels and Genes that are modulated by elevated homocysteine levels. Defects of these genes, primarily due to single nucleotide polymorphism (SNP) alter the homocysteine metabolism, often resulting elevated homocysteine levels. They include not only the genes that code for the enzymes involved in homocysteine metabolism, but also genes that code for the enzymes involved in metabolism of cofactors (vitamin B6 and vitamin B12) or co substrates which are needed for homocysteine homeostasis (Kluijtmans et al., 2003).

Homocysteine modulate these genes either by altering their methylation status or by unknown mechanisms. Defects of these genes cause variable diseases. Most of these gene products are enzymes involved in homocysteine metabolism. Rare mutations of these genes cause severe hyperhomocysteinaemia with characteristic clinical features. Even though any types of mutations are possible in these genes theoretically, single and repeat nucleotide polymorphisms are the commonest genetic variants reported by the researchers (Brulhart et al., 1997). 


\section{Clinical Signs and Symptoms}

There are no symptoms at all in MTHFR gene mutations, but they can cause severe irreversible health conditions. Environmental poisoning can increase when not enough Homocysteine gets converted into Glutathione. Glutathione is most powerful antioxidant and responsible for detoxifying the body from the environmental heavy metals. Some symptoms of this can be: nausea, diarrhoea, abdominal pain, liver and kidney dysfunction, hypertension, tachycardia, pulmonary fibrosis, asthma, immune problems, hair loss and rashes (Ueland et al., 2001).

Central Nervous System disorders can be caused by homocysteine not getting converted into SAMe. SAMe is responsible for Serotonin, Dopamine, and Norepinephrine (neurotransmitters responsible for mood and motivation) production. Cardiovascular problems often occur when Homocysteine levels in the body are too high. Heart attack, Stroke, Blood clots, Peripheral neuropathy, Anemia even Miscarriages and Congenital birth defects can be related to this issue among others. These problems are typically more related to the C677T gene mutation (Wilcken, 2003).

\section{Diagnosis}

In blood circulation $80-90 \%$ of homocysteine molecules are protein bounded, $10-20 \%$ of the total homocysteine is present as homocysteine-cysteine mixed disulfide and homocystine dimer and less than $1 \%$ remaining is present as a free reduced form (Brustolin, Giugliani and Félix, 2010). Blood homocysteine level can be measured through a routine blood test. Before the collection of blood sample fasting is probably not necessary, as shortterm dietary factors will not affect the test results (van der Griend et al., 1998).

Methionine-load test is the other one used to measure the homocysteine level. Homocysteine level is measured before and after the intake of $100 \mathrm{mg} / \mathrm{kg}$ of methionine dissolved in orange juice (Varga et al., 2005). This test is commonly used to diagnose abnormal homocysteine metabolism in people who have a high risk for cardiovascular disease with normal baseline homocysteine levels (Suliman, 2001). There are fairly variable classifications for what can be considered as an elevated homocysteine level. Typically, homocysteine level less than 13 $\mu \mathrm{mol} / \mathrm{L}$ is considered as normal level and level between $13 \mu \mathrm{mol} / \mathrm{L}$ and $60 \mu \mathrm{mol} / \mathrm{L}$ is moderately elevated, and a value greater than $60 \mu \mathrm{mol} / \mathrm{L}$ to 100 $\mu \mathrm{mol} / \mathrm{L}$ is strictly elevated (Varga et al., 2005). These are serum level diagnosis. The above tests are based on looking at biochemical markers to evaluate serum homocystein level. However, to analyse the genetic polymorphism of the MTHFR gene flanking C677T mutation, and several molecular based tests can be employed.

Several techniques have been developed in different countries for the immediate detection of this mutation with high throughput and in narrowed period of time. Those techniques are including PCR, Fluorescence scanning, MS-PCR, Allele specific PCR, and microarray technology. These techniques are fast and strong but in other hand they are highly expensive. For cost effective and easy screening of large number of samples PCR-RFLP has also been developed (Koksal et al., 2006). Restriction fragment length polymorphism (RFLP) analysis is used to identify a change in the genetic sequence that occurs at a site where a restriction enzyme cuts. RFLP can be used to trace inheritance patterns, identify specific mutations, and for other molecular genetic techniques (Samtani et al., 2013). Even though the southern blotting technique is accurate, PCR PFLP is used in this project. In disease diagnostic purposes it is important to provide the results with in a particular time therefore PCR RFLP is more preferable than the southern blotting (Samtani et al., 2013).

\section{Treatment}

Usually, those who with C677T mutations have decreased ability to produce methylfolate, increased cardiovascular risk, increased risk of blood clots, increased pain and inflammation and increased chemical sensitivity. Therapeutic measures are used to increasing the body's inherent ability to restore function and to reduce these adverse effects (Crider $e t$ al., 2012).Basic goal of this treatment is to lower the level of homocysteine to normal. Treatment may consist of giving supplements of folic acid, vitamin B-12 and vitamin B-6. It also may include anticoagulant medications such as aspirin, clopidogrel, heparin, low-molecular weight heparin, or warfarin, to prevent the formation of blood clots. 
Patients with the severe form of hyperhomocysteinemia are often treated with high doses of vitamin B-6 or betaine, and the amount of methionine consumed in the diet may be restricted (Yasui et al., 2000).

Now a day MTHFR mutations can be easily diagnosed in the laboratories. Person who have one or more of the gene mutations can supplement with methyl-folate and methyl B12 (active forms of these $B$ vitamins). They can be supplement with liposomal or acetyl-glutathione. Glutathione drugs are poorly absorbed so either the liposomal form or a precursor, called as n-acetylcysteine (NAC) can be used (Ueland et al., 2001). There are other medicines also, that contain methyl-folate: Deplin, MetanX, CerefolinNAC are a few. Methyl B12 can also be given as shots, nasal sprays, and sublingually. The intramuscular shots are the most effective method (Varga et al., 2005).

\section{Prevalence}

Prevalence studies of MTHFR C677T polymorphism in Sri Lankan populations are unexpectedly sparse even though several researchers proving that hyperhomecysteinaemia were significantly associated with ischaemic heart disease in Sri Lankans. Particular study reported that, a lower prevalence for $\mathrm{T}$ allele (4.5\%) frequency after studying 67 Sri Lankans. This percentage is an unexpected finding since other Asian populations have higher values (Mendis et al., 2002). Another wide-ranging study involving 80 Sinhalese, 80 Tamils and 80 Moors reported prevalence figures of $13 \%, 9 \%$ and $9 \%$ respectively for each ethnic group. Still these values can be considered as comparatively low and this study reveals that the highest prevalence of MTHFR polymorphism is among Sri Lankan Sinhalese compared to Tamils and Moors (Dissanayake et al., 2009). Similar study on Tamils in southern India also reported lower prevalence of $(10.4 \%)$ (Angeline et at., 2004).

Genetic polymorphism is a population reliant on phenomenon. Researchers have reported varying frequency of MTHFR C677 T polymorphism in every population they tested. The $\mathrm{T}$ allele frequency is higher in European and Asian populations compared to Africans and Americans while the least prevalence was reported in Africa. They reached the conclusion after studying 881 unrelated individuals from 16 worldwide populations. In fact they attributed the higher prevalence of myocardial infarction and neural tube defects in Europeans than in Africans to the variation of the $\mathrm{T}$ allele frequency in the two populations (Schneider et al., 1998).Their findings were complemented by analysing the polymorphism in over 7000 new-borns from 16 different areas in the world. They concluded that the variation of polymorphism depend not only on racial or ethnic background, but also the geographical location of the study population too (Wilcken et al., 2003).

\section{OBJECTIVES}

\section{General objective-}

To identify the prevalence of methylenetetrahydrofolatereductase (MTHFR) gene mutation in a group of Sri Lankan patients and seeking routine diagnostic testing for the C677T mutation through the PCR based diagnostic methods

\section{Specific objective -}

To identify the prevalence of mutation in sample population.

To establish PCR for MTHFR gene flanking C677T mutation.

To establish Restriction fragment length polymorphisms (RFLP).

\section{METHODOLOGY}

\section{Extraction of genomic DNA from human blood}

Eight samples were used and DNA was extracted using ceygen column based extraction kit (Ceygen biotech, Colombo) according to manufacturer's instructions.

In a $1.5 \mathrm{ml}$ micro centrifuge tube $200 \mu \mathrm{l}$ of Binding Buffer (BB) and $40 \mu \mathrm{l}$ of Protenase $\mathrm{K}$ were added to $200 \mu \mathrm{l}$ of blood. Mixture was vortexed and incubated at $56^{\circ} \mathrm{C}$ for 10 minutes. Tube was centrifuged to remove any drops from the inside of the lid and 100 $\mu 1$ of Isopropanol was added. Then the mixture was vortexed. Mixture was transferred to a GenospinG ${ }^{\text {TM }}$ column in a collection tube and Centrifuge at 8000rpm for 1 minute. Flow through liquid was 
discarded from the collection tube. $500 \mu \mathrm{l}$ of Inhibition Removal Buffer (IRB) was added to the column and centrifuged at $8000 \mathrm{rpm}$ for 1 minute. Then flow through liquid was discarded. $500 \mu 1$ of Wash Buffer (WB) was added to the column, centrifuged at $8000 \mathrm{rpm}$ for 1 minute and then flow through liquid was discarded. This step was done twice. Empty column was centrifuged at $13000 \mathrm{rpm}$ for 10 seconds. The GenoSpin $\mathrm{G}^{\mathrm{TM}}$ was placed in microcenrtifuge tubes and $50 \mu \mathrm{l}$ of Elution Buffer (EB) was added. It was kept at room temperature for 5 minutes and then centrifuged at $8000 \mathrm{rpm}$ for 1 minute. Then the GenoSpin $\mathrm{G}^{\mathrm{TM}}$ column was discarded and the extracted DNA was kept at $-20^{\circ} \mathrm{C}$ until further analysis.

\section{Polymerase chain reaction (PCR) amplification procedure of extracted DNA}

Table - 01: PCR reagents

\begin{tabular}{|l|l|l|}
\hline Reagents & $\begin{array}{l}\text { Volumes } \\
(\mu \mathrm{l})\end{array}$ & $\begin{array}{l}\text { Volumes } \\
(\mu \mathrm{l}) \mathrm{x} 10\end{array}$ \\
\hline PCR water & 7.5 & 75 \\
\hline Ceygen master mix & 10.0 & 100 \\
\hline $\begin{array}{l}\text { MTHFR 1primer } \\
(10 \mu \mathrm{M})\end{array}$ & 1.0 & 10 \\
\hline $\begin{array}{l}\text { MTHFR 2primer } \\
(10 \mu \mathrm{M})\end{array}$ & 1.0 & 10 \\
\hline $\begin{array}{l}\text { Tag polymerase } \\
\text { 5U/ } \mu \mathrm{l}\end{array}$ & 0.5 & 05 \\
\hline Template DNA & 5.0 & - \\
\hline Total & 25.0 & 200 \\
\hline
\end{tabular}

$200 \mu \mathrm{l}$ of PCR mix was prepared with reagents mentioned in the table 01. It was aliquot into 10 PCR tubes to prepare positive control, negative control and 8 samples. Each PCR tube contained $20 \mu 1$ of PCR master mix and then $5 \mu$ l of DNA template and PCR water or known positive DNA in test samples, negative control and positive control respectively.

MTHFR C677T amplification was performed with qualitative polymerase chain reaction. Extracted DNA was amplified by PCR using primer pair MT-1 and MT-2. The sequences of the primers are shown below. These specific primers flank the polymorphism spanning a 223 base pair region of the MTHFR gene.
Table - 02 MT-1 and MT-2 Primer sequences (Leclerc, Sibani and Rozen, 2000).

\begin{tabular}{|l|l|}
\hline Primer & Sequence \\
\hline MT- 1 & 5'- \\
& TTGAGGCTGACCTGAAGCACTT \\
& G -3' \\
\hline MT-2 & $\begin{array}{l}\text { ' }- \\
\text { AGGACGGTGCGGTGAGAGTG-3' }\end{array}$ \\
\hline
\end{tabular}

Cyclic parameters for MTHFR PCR programme

$$
\begin{aligned}
& \text { Initial denaturation at } 95^{\circ} \mathrm{C} \text { for } 05 \text { minutes } \\
& \text { Denaturation at } 94^{\circ} \mathrm{C} \text { for } 30 \text { seconds } \\
& \text { Annealing at } 55^{\circ} \mathrm{C} \text { for } 30 \text { seconds } 30 \text { Cycles } \\
& \text { Extension at } \quad 72^{\circ} \mathrm{C} \text { for } 45 \text { seconds } \\
& \text { Final extension at } \quad 72^{\circ} \mathrm{C} \text { for } 05 \text { minutes } \\
& \text { Final hold at } 20^{\circ} \mathrm{C}
\end{aligned}
$$

\section{RFLP assay for PCR products}

Before the establishment of RFLP PCR products were run under the gel electrophoresis to confirm the presence of PCR bands. $140 \mu$ l of restriction digestion mix was prepared with reagents mentioned in the table 03. For restriction digestion, each tube contained $14 \mu \mathrm{l}$ of the restriction digestion mixture and $1 \mu \mathrm{l}$ of known positive PCR product and the negative control vial contained $1 \mu$ l of water. Samples were kept for overnight incubation at $37^{\circ} \mathrm{C}$ and then kept for 20 minutes in $80^{\circ} \mathrm{C}$ to inactivate Hind 111 enzyme.

Table- 03: Restriction digestion of PCR product

\begin{tabular}{|l|l|l|}
\hline Reagents & Volumes $(\mu \mathrm{l})$ & $\begin{array}{l}\text { Volumes }(\mu \mathrm{l}) \\
\mathrm{x} 10\end{array}$ \\
\hline PCR water & 7.5 & 75 \\
\hline Buffer 2 & 1.5 & 15 \\
\hline $\begin{array}{l}\text { Hind } 111 \\
\text { enzyme }\end{array}$ & 5.0 & 50 \\
\hline PCR product & 1.0 & - \\
\hline Total & 15.0 & 140 \\
\hline
\end{tabular}




\section{Preparation of agarose gel and gel electrophoresis}

$70 \mathrm{ml}$ of TBE buffer was measured and taken in to the conical flask. 1.2g of Agarose powder was taken and mixed with it. Conical flask was covered with aluminum foil and heated in a microwave oven for 2 minutes and 20 seconds until all the solids were completely melted. Then $4.5 \mu$ of ethidium bromide was added to the solution and then it was poured into a gel casting tray with a comb for the preparation of wells and it was allowed to solidify about 40-50 minutes at room temperature. After the gel was solidified comb was removed and then the gel was placed in the electrophoresis chamber and covered with TBE buffer.

\section{Detection and analysis}

$10 \mu \mathrm{l}$ of positive control and sample products were added with $2 \mu$ of loading dye separately; mixed well and loaded into the gel. Positive control, samples and one uncut PCR product were loaded. $500 \mathrm{ng}$ of molecular weight marker was loaded in to the first lane of the gel. Gel was run under 100- $120 \mathrm{~mA}$ electric field for 30- 45 minutes. Finally migrated DNA bands were visualized under UV trans illuminator.

\section{RESULTS}

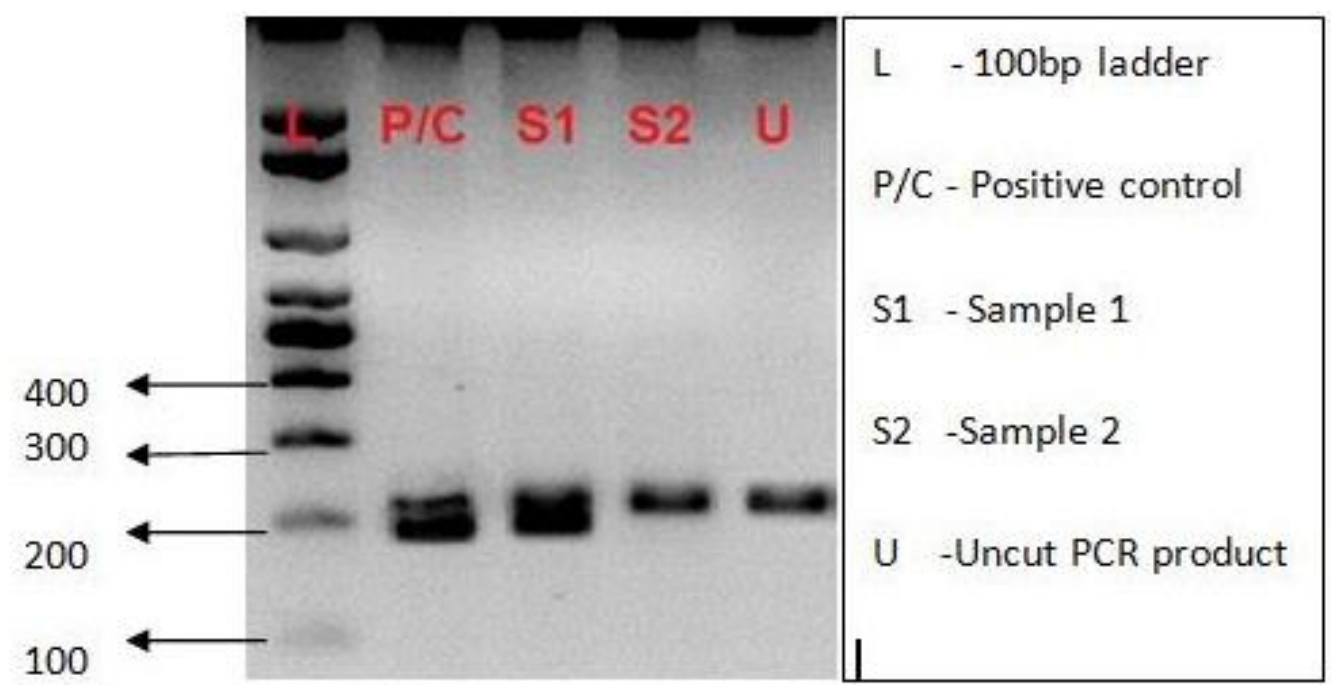

Figure 03-Gel picture of sample 1 and sample 2 MTHFR genotypes

Sample1 is heterozygous (CT) genotype

Sample 2 is homozygous (CC) genotype 


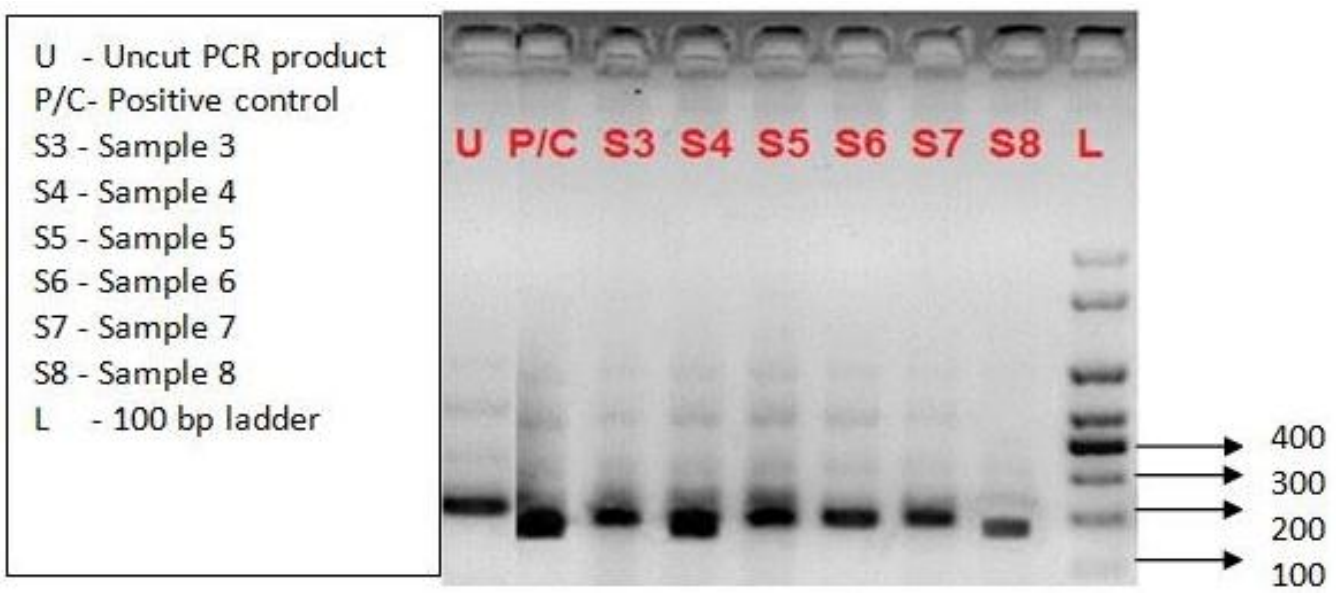

Figure 04-Gel picture of MTHFR genotypes from sample 3 to sample 8

Sample 4 is the heterozygous (CT) genotype

Sample 8 is the homozygous (TT) genotype

Other samples are homozygous (CC) genotype

Table 04: Interpretation of MTHFR C677T polymorphism

\begin{tabular}{|c|c|c|}
\hline Genotype & Number of bands expected & Number of bands visible \\
\hline Homozygous (CC) & 1 (223 bp) & 1 (223 bp) \\
\hline Homozygous (TT) & 2 (25 bp and 198 bp) & 1 (198bp) \\
\hline Heterozygous (CT) & 3 (25 bp,198 bp and 223 bp) & 2 (198 bp and 223 bp) \\
\hline
\end{tabular}

Chart 01: Percentage of MTHFR genotypes in Sri Lankans

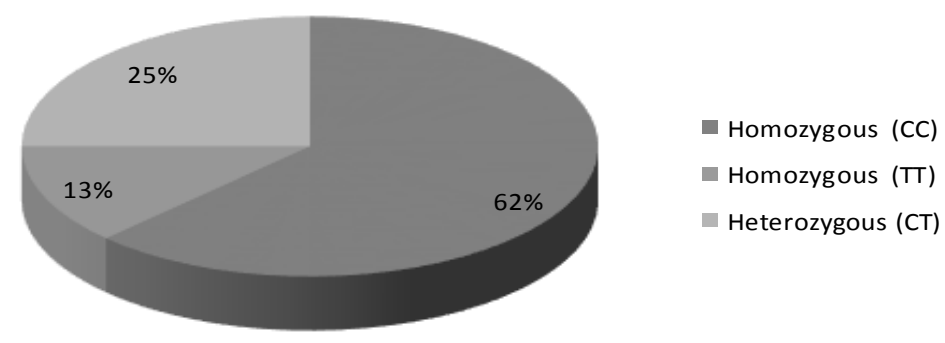


The substitution of "C" to "T" at 677 position of MTHFR gene creates a restriction site for the enzyme Hind111. Restriction digestion of the 677TT amplicon results two fragments of $198 \mathrm{bp}$ and $25 \mathrm{bp}$ while the 677CC amplicon does not undergo digestion. As a result the homozygous 677CC genotype (wild type) would give rise to one band of $223 \mathrm{bp}$ in the electrophoresed gel while the homozygous 677TT genotype would produce 2 bands of $25 \mathrm{bp}$ and $198 \mathrm{bp}$ in length. Also the heterozygous $677 \mathrm{CT}$ genotype would give rise to 3 bands of $25 \mathrm{bp}$, $198 \mathrm{bp}$ and 223bp in length.

\section{DISCUSSION}

Among the 8 samples tested 2 were had heterozygous 677CT genotype, one had homozygous 677TT genotype and the other 5 had $677 \mathrm{CC}$ wild type. Homozygous TT genotype is considered as harmful because it is associated with high concentration of total plasma Homocysteine level and lower MTHFR enzyme activity of $30 \%$. On the other hand, 677CT genotype has MTHFR enzyme activity of about $65 \%$ when compared to wild type (Curtin et.al, 2004). The substitution of " $\mathrm{T}$ " for "C" at 677 position of MTHFR gene creates a restriction site for the enzyme Hind111 (Koksal et al., 2007). During electrophoresis of the PCR products $25 \mathrm{bp}$ fragment migrates out of the gel due to the small fragment size. Therefore, it is not visible in the gel. But that did not hinder the genotype differentisingle bands of two homozygous genotypes were of different sizes which can be easily separated using the marker DNA (Samtani et al., 2013).

The primer melting temperature can indicate DNADNA hybrid stability and it is important for the optimization of PCR annealing temperature (Ta). Really high Ta values can cause insufficient primertemplate hybridization and produce less PCR products; in turn low annealing temperatures can cause a high number of primer mis pairings and formation of non-specific bands. The GC content is related to the primer melting temperature and plays a role in the annealing step of PCR. A previous study reported that a GC content of $45-60 \%$ results in more specific hybridization. Maintain the melting temperature above $50^{\circ} \mathrm{C}$ is important to avoid the formation of non-specific bands (Loo, Griffiths and Gan, 2012). Considering the fact that MTHFR C677T polymorphism is the commonest cause for hyperhomocysteinaemia, the heterogeneity of the results of the individual studies could be due to the variation of the population prevalence of the $\mathrm{T}$ allele. Although a lot of gaps exist in $\mathrm{T}$ allele distribution data in our country, it is widely expected for the prevalence to be varied significantly among different ethnic groups even in the same locality. Vitamin status especially B 12 and Folic acid influence the homocysteine level and in turn the heterogeneity of the study results. Other genetic and environmental factors too can contribute for the variation of the results of the different studies, but the relative contribution of them to the final outcome is difficult to assess (Leclerc, Sibani and Rozen, 2000).

In similar studies, it seems that conclusion of each individual study should be interpreted in the context of ethnic origin, geographical background, vitamin status of the sample population and the prevalence of the $\mathrm{T}$ allele in the particular ethnic groups. Prevalence of MTHFR C677T mutation differs in various populations and decreasing from East to West. According to the most comprehensive study up to date, $\mathrm{T}$ allele frequency is $34-44 \%$ in China, $25-46 \%$ in Europe, $21-41 \%$ in America and $28 \%$ in Australia. The highest frequency was reported in Mexico (57\%) while the lowest frequency was reported among American blacks (12.6\%) (Wilcken et al., 2003). Similar study reported that allele frequency in Africa $(6.6 \%)$ was the lowest and comparable to Sri Lanka (4.5\%) (Cronin et al., 2005). The observed frequency of MTHFR C677T in the presently studied population (even though ethnic groups not included) is higher than that reported Cronin on 2005 but it is comparable to the frequencies reported by Dissanayake on 2009. Although this study was conducted with in the small sample population and the extension of the research work to include larger sample population with ethnic groups in Sri Lanka was limited by the time, research period and financial constraints.

Therapeutic interventions if any would be in the form of vitamin (Folic acid and vitamin B12 mainly) supplementation for a patient with high homocysteine level due to the presence of the polymorphism, since it has been established fact that folic acid has a significant homocysteine lowering effect which is increased by the addition of vitamin B 12 (Yasui et 
al., 2000). High intake of folate, which is plentiful in vegetables and fruits, has been related with reduced risk of several cancers (Leclerc, Sibani and Rozen, 2000). Folate deficiency was suggested to increase the risk of cancer through impaired DNA repair and disruption of DNA methylation that may lead to proto-oncogene activation (Varga et al., 2005). Preventive measures such as food fortification with folic acid and vitamin B 12 can be started if the vitamin status of the population is lower or the prevalence of $\mathrm{T}$ allele is higher in the target population. FDA approved programme for folic acid fortification of cereal and grain products was initiated in USA in 1998 and post fortification analysis of its effects on homocysteine level is still underway (Leclerc, Sibani and Rozen, 2000).

In summary, related studies has shown that, even though lower frequency of MTHFR C677T polymorphism is present in Sri Lankans the frequency is increasing over the year. But the present study has many limitations. Limited numbers of participants, failure to include Sri Lankan ethnic groups and also sample details are blinded. The financial and time constrains were the main reasons for the above mentioned limitations. Future studies with larger sample population, looking at different ethnic groups in different parts of the country, study of homocysteine level and nutritional status of the population together with MTHFR genotype will give better and accurate frequency of MTHFR C677T polymorphism in Sri Lanka.

\section{CONCLUSION}

The results obtained from this study shows that, of the 8 samples tested, 2 had 677CT genotype, 1 had $677 \mathrm{TT}$ genotype whereas the remaining 5 had $677 \mathrm{CC}$ wild type. In the last decade several studies had been conducted to discover the direct or indirect influence of increased levels of homocysteine in several diseases. These studies confirmed that several polymorphisms in genes which are related to folate and homocysteine methionine pathway result hyperhomocysteinemia and suggesting that these variants may play a major role in many multifactorial disorders which are high prevalence in the world wide population. Folic acid supplements with vitamin B12 are better and cost effective way to decrease hyperhomocysteinemia. However, as this is a small sample of the population, it is recommended to carry out studies with a large sample volume to ascertain the prevalence of this mutation in the community. RFLP and PCR based diagnostic methods are useful for the identification of these mutations.

\section{ACKNOWLEDGEMENT}

I would like to express my gratitude and appreciation to all those whogave me the possibility to complete this report. A special thanks goes tomy project supervisor, Prof. Aresha Manamperi, University of kelaniya who gave propersuggestions, encouragement and helpful in areas where the guidancewas much necessary. I wish to thank my lecturers, tutors, facilitators (Durdans hospital molecular diagnostic laboratory) family and friends who gave me a great support to finish my research project successfully.

\section{REFERENCES}

Angeline, T., Thiruvarutselvi, G., Isabel, W., Aruna, R. M., Devi, R. and Jeyaraj, N. (2009) MTHFR (Ala 222 Val) polymorphism and AMI in patients with type II diabetes mellitus., Indian journal of clinical biochemistry: IJCB, 24(2), pp. 137-41

Barbosa, P. R., Stabler, S. P., Machado, A. L. K., Braga, R. C., Hirata, R. D. C., Hirata, M. H., Sampaio-Neto, L. F., Allen, R. H. and Guerra-Shinohara, E. M. (2008) Association between decreased vitamin levels and MTHFR, MTR and MTRR gene polymorphisms as determinants for elevated total homocysteine concentrations in pregnant women., European journal of clinical nutrition, Macmillan Publishers Limited, 62(8), pp. 1010-21

Blom, H. J. (2009) Folic acid, methylation and neural tube closure in humans., Birth defects research. Part A, Clinical and molecular teratology, 85(4), pp. 295-302

Blom, H. J. and Smulders, Y. (2011) Overview of homocysteine and folate metabolism. With special references to cardiovascular disease and neural tube defects., Journal of inherited metabolic disease, 34(1), pp. $75-81$

Brulhart, M. C., Dussoix, P., Ruiz, J., Passa, P., Froguel, P. and James, R. W. (1997) The (Ala-Val) mutation of methylenetetrahydrofolate reductase as a genetic risk factor for vascular disease in non-insulin-dependent diabetic patients., American journal of human genetics, 60(1), pp. 228-9

Brustolin, S., Giugliani, R. and Félix, T. M. (2010) Genetics of homocysteine metabolism and associated disorders., Brazilian journal of medical and biological research $=$ Revista brasileira de pesquisas médicas $\mathrm{e}$ biológicas / Sociedade Brasileira de Biofísica ... [et al.], 43(1), pp. 1-7

Crider, K. S., Yang, T. P., Berry, R. J. and Bailey, L. B. (2012) Folate and DNA methylation: a review of molecular mechanisms and the evidence for folate's role., Advances in nutrition (Bethesda, Md.), 3(1), pp. 21-38 
Cronin, S., Furie, K. L. and Kelly, P. J. (2005) Dose-related association of MTHFR 677T allele with risk of ischemic stroke: evidence from a cumulative meta-analysis., Stroke; a journal of cerebral circulation, 36(7), pp. 1581-7

Curtin, K. (2004) MTHFR C677T and A1298C Polymorphisms: Diet, Estrogen, and Risk of Colon Cancer, Cancer Epidemiology Biomarkers \& Prevention, 13(2), pp. 285-292

Deeparani, T., Pillai, M. R. and Elavazhagan, T. (n.d.) Detection of MTHFR C677T and A1298C Gene Polymorphism in Congenital Heart Disease, [online] Available

from: http://www.researchgate.net/publication/239557433_Detect ion_of_MTHFR_C677T_and_A1298C_Gene_Polymorphis m_in_Congenital_Heart_Disease (Accessed 12 May 2015).

Dissanayake, V. H. W., Weerasekera, L. ., Gammulla, C. G. and Jayasekara, R. W. (n.d.) Prevalence of genetic thrombophilic polymorphisms in the Sri Lankan population - implications for association study design and clinical genetic testing services, [online] Available from: http://archive.cmb.ac.lk/research/handle/70130/1956 (Accessed 13 May 2015).

Ford, E. S. (2002) Homocyst(e)ine and cardiovascular disease: a systematic review of the evidence with special emphasis on case-control studies and nested case-control studies, International Journal of Epidemiology, 31(1), pp. 59-70

Forges, T., Monnier-Barbarino, P., Alberto, J. M., GuéantRodriguez, R. M., Daval, J. L. and Guéant, J. L. (2007) Impact of folate and homocysteine metabolism on human reproductive health., Human reproduction update, 13(3), pp. $225-38$

Frosst, P., Blom, H. J., Milos, R., Goyette, P., Sheppard, C. A., Matthews, R. G., Boers, G. J., den Heijer, M., Kluijtmans, L. A. and van den Heuvel, L. P. (1995) A candidate genetic risk factor for vascular disease: a common mutation in methylenetetrahydrofolate reductase., Nature genetics, 10(1), pp. 111-3

Gallagher, P. M., Meleady, R., Shields, D. C., Tan, K. S., McMaster, D., Rozen, R., Evans, A., Graham, I. M. and Whitehead, A. S. (1996) Homocysteine and Risk of Premature Coronary Heart Disease: Evidence for a Common Gene Mutation, Circulation, 94(9), pp. 21542158

Gilbody, S., Lewis, S. and Lightfoot, T. (2007) Methylenetetrahydrofolate reductase (MTHFR) genetic polymorphisms and psychiatric disorders: a HuGE review., American journal of epidemiology, 165(1), pp. 1-13

Graham, I., Refsum, H., Rosenberg, I. H., Ueland, P. M. and Shuman, J. M. (eds.) (1997) Homocysteine Metabolism: From Basic Science to Clinical Medicine, Developments in Cardiovascular Medicine, Boston, MA, Springer US, [online] Available from: http://www.springerlink.com/index/10.1007/978-1-46155771-5 (Accessed 13 May 2015).

Husemoen, L. L. N., Linneberg, A., Fenger, M., Thuesen, B. H. and Jørgensen, T. (2009) Changes in lifestyle, biological risk factors and total homocysteine in relation to MTHFR C677T genotype: a 5-year follow-up study., European journal of clinical nutrition, Macmillan Publishers Limited, 63(10), pp. 1233-40
Jacques, P. F., Bostom, A. G., Williams, R. R., Ellison, R. C., Eckfeldt, J. H., Rosenberg, I. H., Selhub, J. and Rozen, R. (1996) Relation between folate status, a common mutation in methylenetetrahydrofolate reductase, and plasma homocysteine concentrations., Circulation, 93(1), pp. 7-9

Kalkan, G., Yigit, S., Karakuş, N., Ateş, O., Bozkurt, N., Ozdemir, A. and Pancar, G. Ş. (2013) Methylenetetrahydrofolate reductase C677T mutation in patients with alopecia areata in Turkish population., Gene, 530(1), pp. 109-12

Karabacak, E., Aydin, E., Ozcan, O., Dogan, B., Gultepe, M., Cosar, A. and Muftuoglu, T. (2014) Methylenetetrahydrofolate reductase (MTHFR) $677 \mathrm{C}>\mathrm{T}$ gene polymorphism as a possible factor for reducing clinical severity of psoriasis., International journal of clinical and experimental medicine, 7(3), pp. 697-702

Kirke, P. N. (2004) Impact of the MTHFR C677T polymorphism on risk of neural tube defects: case-control study, BMJ, 328(7455), pp. 1535-1536

Kluijtmans, L. A. J., Young, I. S., Boreham, C. A., Murray, L., McMaster, D., McNulty, H., Strain, J. J., McPartlin, J., Scott, J. M. and Whitehead, A. S. (2003) Genetic and nutritional factors contributing to hyperhomocysteinemia in young adults., Blood, 101(7), pp. 2483-8

Koksal, V., Baris, I. and Etlik, O. (2007) Primer-engineered multiplex PCR-RFLP for detection of MTHFR C677T, prothrombin G20210A and factor V Leiden mutations., Experimental and molecular pathology, 83(1), pp. 1-3

Kruman, I. I., Kumaravel, T. S., Lohani, A., Pedersen, W. A., Cutler, R. G., Kruman, Y., Haughey, N., Lee, J., Evans, M. and Mattson, M. P. (2002) Folic acid deficiency and homocysteine impair DNA repair in hippocampal neurons and sensitize them to amyloid toxicity in experimental models of Alzheimer's disease., The Journal of neuroscience: the official journal of the Society for Neuroscience, 22(5), pp. 1752-62

Leclerc, D., Sibani, S. and Rozen, R. (2000) Molecular Biology of Methylenetetrahydrofolate Reductase (MTHFR) and Overview of Mutations/Polymorphisms, Landes Bioscience, [online] Available from: http://www.ncbi.nlm.nih.gov/books/NBK6561/ (Accessed 11 May 2015).

Liang, Y., Li, Y., Li, Z., Liu, Z., Zhang, Z., Chang, S. and Wu, J. (2012) Mechanism of folate deficiency-induced apoptosis in mouse embryonic stem cells: Cell cycle arrest/apoptosis in G1/G0 mediated by microRNA-302a and tumor suppressor gene Lats2., The international journal of biochemistry \& cell biology, 44(11), pp. 1750-60

Loo, K. W., Griffiths, L. R. and Gan, S. H. (2012a) A novel multiplex PCR-RFLP method for simultaneous detection of the MTHFR $677 \mathrm{C}>\mathrm{T}$, eNOS $+894 \mathrm{G}>\mathrm{T}$ and - eNOS -786 $\mathrm{T}>\mathrm{C}$ variants among Malaysian Malays., BMC medical genetics, 13(1), p. 34

Mansoori, N., Tripathi, M., Luthra, K., Alam, R., Lakshmy, R., Sharma, S., Arulselvi, S., Parveen, S. and Mukhopadhyay, A. K. (2012) MTHFR (677 and 1298) and IL-6-174 G/C genes in pathogenesis of Alzheimer's and vascular dementia and their epistatic interaction., Neurobiology of aging, Elsevier, 33(5), pp. 1003.

Mendis, S., SBP, A. and Kenji, T. (1997) Association between hyperhomocysteinemia and ischemic heart disease 
in Sri Lankans, International Journal of Cardiology, Elsevier, 62(3), pp. 221-225

Micheal, S., Qamar, R., Akhtar, F., Khan, M. I., Khan, W. A. and Ahmed, A. (2009) MTHFR gene C677T and A1298C polymorphisms and homocysteine levels in primary open angle and primary closed angle glaucoma, Molecular Vision, [online] Available from: http://www.molvis.org/molvis/v15/a244/ (Accessed 4 May 2015).

Samtani, R., Kaur, L., Saraswathy, K. N. and Ghosh, P. K. (2013) Title: Simultaneous detection of FVL and MTHFR (C677T) mutations using PCR RFLP method, [online] Available from: http://www.researchgate.net/publication/236165857_Title_ Simultaneous_detection_of_FVL_and_MTHFR_(C677T) mutations_using_PCR_RFLP_method (Accessed 4 May 2015).

Schmitz, C., Lindpaintner, K., Verhoef, P., Gaziano, J. M. and Buring, J. (1996) Genetic Polymorphism of Methylenetetrahydrofolate Reductase and Myocardial Infarction: A Case-Control Study, Circulation, 94(8), pp. $1812-1814$

Schneider, J. A., Rees, D. C., Liu, Y. T. and Clegg, J. B. (1998) Worldwide distribution of a common methylenetetrahydrofolate reductase mutation., American journal of human genetics, 62(5), pp. 1258-60

Spotila, L. D. (2003) Age Dependence of the Influence of Methylenetetrahydrofolate Reductase Genotype on Plasma Homocysteine Level, American Journal of Epidemiology, 158(9), pp. 871-877
Suliman, M. E. (2001) Effects of methionine loading on plasma and erythrocyte sulphur amino acids and sulphhydryls before and after co-factor supplementation in haemodialysis patients, Nephrology Dialysis Transplantation, 16(1), pp. 102-110

Trovato, F. M., Catalano, D., Ragusa, A., Martines, G. F., Pirri, C., Buccheri, M. A., Di Nora, C. and Trovato, G. M. (2015) Relationship of MTHFR gene polymorphisms with renal and cardiac disease., World journal of nephrology, 4(1), pp. 127-37

Ueland, P. M., Hustad, S., Schneede, J., Refsum, H. and Vollset, S. E. (2001) Biological and clinical implications of the MTHFR C677T polymorphism, Trends in Pharmacological Sciences, 22(4), pp. 195-201

Van der Griend, R., Haas, F. J., Duran, M., Biesma, D. H., Meuwissen, O. J. and Banga, J. D. (1998) Methionine loading test is necessary for detection of hyperhomocysteinemia., The Journal of laboratory and clinical medicine, 132(1), pp. 67-72

Varga, E. A., Sturm, A. C., Misita, C. P. and Moll, S. (2005) Cardiology patient pages. Homocysteine and MTHFR mutations: relation to thrombosis and coronary artery disease., Circulation, 111(19), pp. e289-93

Weisberg, I. (2001) The $1298 \mathrm{~A} \rightarrow \mathrm{C}$ polymorphism in methylenetetrahydrofolate reductase (MTHFR): in vitro expression and association with homocysteine, Atherosclerosis, 156(5), pp. 409-415

Wilcken, B. (2003) Geographical and ethnic variation of the $677 \mathrm{C}>\mathrm{T}$ allele of 5,10 methylenetetrahydrofolate reductase (MTHFR): findings from over 7000 newborns from 16 areas world wide, Journal of Medical Genetics, 40(8), pp. 619-625

Yasui, K., Kowa, H., Nakaso, K., Takeshima, T. and Nakashima, K. (2000) Plasma homocysteine and MTHFR C677T genotype in levodopa-treated patients with PD, Neurology, 55(3), pp. 437-440

Zhang, M.-J., Li, J.-C., Yin, Y.-W., Li, B.-H., Liu, Y., Liao, S.-Q., Gao, C.-Y. and Zhang, L.-L. (2014) Association of MTHFR C677T polymorphism and risk of cerebrovascular disease in Chinese population: an updated meta-analysis., Journal of neurology, 261(5), pp. 925-35 